\title{
REPORT
}

\section{A Report on National Seminar "Ecology, Environment and Religions: Key Issues and Challenges"}

\author{
Kanchan Bharati ${ }^{*}$ and Dhananjay Kumar ${ }^{* *}$
}

The relationship between human and environment is one of the fundamental and most debated issues in the present day. Human beings are an imperative part and manipulators of the ecosystems. The integrity and functionality of vital natural assets like forests, lakes, rivers, land etc., are increasingly being compromised. Change in environment and ecology is more of a moral challenge. It calls us to examine how we use and share the goods of the earth, what we pass on to future generations, and how we live in harmony with interfaith traditions (Gottlieb 2006). Basically, it deals with what human being practices which depend upon their ideology. As Lynn White (1967) observed, "what people do about their ecology depends on what they think about themselves in relation to things around them. Human ecology is deeply conditioned by beliefs about our nature and destiny-that is, by religion". Due to this epistemological emphasis, ecology and religion is an emerging area of study, research, and engagement that embraces multiple disciplinary subjects in an attempt to integrate discussions that have occurred in largely separate circles (Leal Filho, Dahms, and ConsorteMcCrea 2019).

So far, discussions organized under the banner of the ecology and religion have generally confined in the specialized departments in the western universities (Grim and Tucker 2014). Moreover, those are more or less

\footnotetext{
* Assistant Professor, Centre for Culture and Development (CCD), XTI Campus, SevasiPost, Vadodara-391101.kbharati82@gmail.com

** Assistant Professor, Centre for Culture and Development (CCD), XTI Campus, SevasiPost, Vadodara-391101. dhananjaykumarnitrkl@gmail.com. $\square$

Copyright (C) Bharati and Kumar 2020. Released under Creative Commons AttributionNonCommercial 4.0 International licence (CC BY-NC 4.0) by the author.

Published by Indian Society for Ecological Economics (INSEE), c/o Institute of Economic Growth, University Enclave, North Campus, Delhi 110007.
}

ISSN: 2581-6152 (print); 2581-6101 (web).

DOI: https://doi.org/10.37773/ees.v3i1.104 
centred on the Eurocentric dialogues. However, scholars, data and field material from India have been slow to follow this lead. This is despite its being a large sub-continent, with its rich and varied ecologies and cultures, and the birthplace of three major and several minor religious traditions.

To address this gap, the Centre for Culture and Development (CCD), Vadodara (Gujarat) with the help of Indian Council of Social Science Research (ICSSR) (Mumbai - India) organized a National Seminar on 'Ecology, Environment and Religions: Key Issues and Challenges' during 26-27, February 2018. It brought together scholars, experts from different disciplinary fields and religious practitioners for two days of informative and stimulating discussions. The seminar aimed at examining the interrelationship between ecology to the human behaviour through the lenses of (i) physical dimension (ii) social dimension and (iii) religious or spiritual dimension.

Well-known water conservationist \& environmentalist, also known as 'Waterman of India', Shri Rajendra Singh, in his keynote address raised a significant point on linking the human, ecology and environment by stating that unless the community is involved in the conversation of the conservation of nature, any concern for environmental preservation is not achievable. Dr. Binny Sareen, Regional Director-Global Peace Initiative for India, in her guest of Honour address gave a spiritual perspective towards maintaining ecological balance and sustainability. Spiritual ecology refers to the intersection between religion, spirituality and environment which can play an important role in controlling not only the outside world positively but also the inner nature.

The seminar began by focusing on the 'Ecology and Biodiversity- HumanEnvironment Relationship' with three presentations. Lancelot D'Cruz emphasized upon the tribal communities, traditional ethnomedicinal wisdom and on the need for documenting and using their traditional knowledge for biodiversity sustainability and conservation. Deepa Gavali argued that communities can help in maintaining ecological biodiversity and conservation by preserving important endangered plant species. Arun Mahato highlighted how Chhota Nagpur's indigenous communities' cultural practices of festivals had contributory elements of preserving biodiversity. The second session focused on the 'Social Dimension of Ecology: SocietyEnvironment Relationship'. Amit Mitra explored the role of markets in linking ecology to religion, the consequence of being an imbalance of ecological sustainability and negative impact on sacred groves conservation. Shashikant Kumar highlighted interweaved nature of urbanization and environmental sustainability, focusing on how regional developments causes environmental problems. Rohit Prajapati delved on the different 
socio-legal dimension of environmental conservation based on legal cases related to development projects with environmental issues. Ramnath $\mathrm{K}$. Rao chronicled various debates on environment, development and women in ecological discourse.

The third session focused on ecologically sustainable development through some case studies. Emphasizing on environment education for students, Jothi Xavier put forwarded a three C's initiative for environment teaching pedagogy which includes - curiosity, creativity and compassion. Dhananjay Kumar's theoretical paper discussed humanity's impact on the Earth's atmosphere and crucial outcome of the dramatic reshaping of the global biosphere - like degradation of forests and agriculture, resource depletion, public health issues, loss of biodiversity and resilience in ecosystems. Jayesh Bhatt remarked about the cases of terrestrial ecosystem loss like habitat alteration, invasive species, pollution, population growth and overexploitation in the Banni Grassland of Kutch. Mahesh Lakum viewed the industry and environmental predicaments from Subaltern lens and pointed the lacuna in existing research on environmental degradation with the chemical and pharmaceutical industry.

The last two sessions, four and five, focused on the religious and spiritual dimension on ecology: religion-environment relationship. Session four has three presentations. Fr. Joseph Mattam presented the concise description of Laudato Siby Pope Francis where it was noted that earth is crying because of the harm humans have inflicted on her because of the use and abuse of the goods. Maulana Mufti Ahmed Devlavi presented some aspects of the Islamic perspective on environmental ethics, pointing existence of more than 750 verses in the Quran related to nature and conservation. Sanjay Rattan highlighted the faith-ecology paradigm of protecting the environment. Linking religious groups to conservation he argued that religious bodies have the influence and ability to shift one of the main drivers of biodiversity loss and climate change. Session five was a panel discussion participated by the scholars and religious leaders representing their respective academic and spiritual views on religion and environment. Through their rigorous discussions, panelists drew our attention to the hope of achieving a goal where development, environmental commitment and spiritual practices can work together to protect and enhance the quality of life on this planet.

Lastly, Jayesh Shah, Ambassador, Parliament of the World's Religions, in his concluding address mentioned that for more than thirty years, the world's major institutions, scientists, governments and the largest NGO's have compiled and analyzed details of how we are abusing the planet and yet the crisis is with us. Each of the faith traditions has something unique to 
offer to humanity and earth. The focus thus, should be on the role each of the faith traditions could play at the ground level based on the sayings of their scriptures or traditions for the conservation and preservation of environment and ecology.

The seminar discussed important questions and concerns for protecting and caring of the earth for today and future generations. By bringing people from diverse sub-fields of environmental science, ethnoecology, political ecology, anthropology, sociology, gender studies, subaltern studies and religious tourism studies the seminar had set out in addressing the challenges to ecology and environment in our troubled world. It made a significant effort for cross-fertilization of ideologies, ideas, methods, theories and philosophies of physical, social and spiritual studies.

\section{ACKNOWLEDGEMENTS}

We thank our colleague Jayesh Shah, Research Consultant, Centre for Culture and Development, who provided insight and expertise that greatly assisted the research, although he may not agree with all of the interpretations of this paper. We would also like to show our gratitude to Lancy Lobo, Director, Centre for Culture and Development, for sharing his pearls of wisdom with us. We also thank "anonymous" reviewers for their insights.

\section{REFERENCES}

Gottlieb, Roger S. 2006. "Introduction: Religion and Ecology—What Is the Connection and Why Does It Matter?" In The Oxford Handbook of Religion and Ecology, 11-16. Oxford University Press. https://doi.org/10.1093/oxfordhb/9780195178722.003.0001.

Grim, John, and Mary Evelyn Tucker. 2014. Ecology and Religion. Washington, D.C.: Island Press.

Leal Filho, Walter, Lena Maria Dahms, and Adriana Consorte-McCrea. 2019. "Sustainability and Religion: Past Trends and Future Perspectives." In Sustainability and the Humanities, edited by Walter Leal Filho and Adriana Consorte McCrea, 61119. Cham: Springer International Publishing. https://doi.org/10.1007/978-3-31995336-6 35 .

White, Lynn. 1967. "The Historical Roots of Our Ecologic Crisis." Science 155 (3767): 1203-7. https://doi.org/10.1126/science.155.3767.1203. 